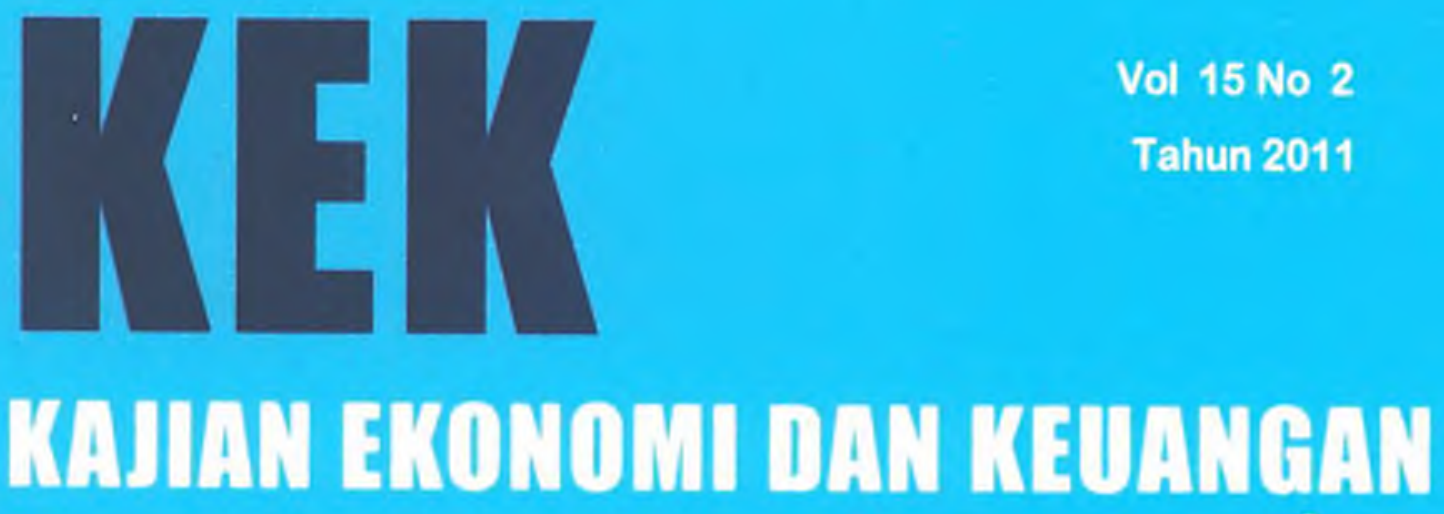

D Potensi Penerimaan Pajak Dari Underground Economy di Indonesia

- Dampak Volatilitas Harga Minyak di Indonesia Terhadap Penyesuaian Keseimbangan Fiskal

- Analisis Permasalahan Pembiayaan UMKM di Indonesia

- Analisis Kesinambungan Transaksi Berjalan Indonesia : 1980-2010

- Perkembangan FDI ke Indonesia dan Langkah Kebijakan yang Diperlukan

\begin{tabular}{|c|c|c|c|c|c|}
\hline Kaj. Eko. \& Keu. & Vol.15 & No. 2 & Jakarta 2011 & $\begin{array}{c}\text { ISSN 1410- } \\
3249\end{array}$ & $\begin{array}{c}\text { Terakreditasi B } \\
\text { (No. Akroditasi : } \\
\text { 306/AU2/P2MB//08/2010) }\end{array}$ \\
\hline
\end{tabular}

Pusat Kebijakan Ekonomi Makro 


\section{KA J I A N}

EKONOMI

KEUANGAN

Pusat Kebijakan Ekonomi Makro

Badan Kebijakan Fiskal

Kementerian Keuangan RI

Potensi Penerimaan Pajak Dari Underground Economy

di Indonesia

Dampak Volatilitas Harga Minyak di Indonesia Terhadap

Penyesuaian Keseimbangan Fiskal

Analisis Permasalahan Pembiayaan UMKM di Indonesia

Analisis Kesinambungan Transaksi Berjalan di Indonesia :

1980-2010

Perkembangan FDI ke Indonesia dan Langkah Kebijakan

Yang Diperlukan

\begin{tabular}{|l|l|l|l|l|}
\hline Kaj. Eko. \& Keu. & Vol. 15 & No.2 & Jakarta 2011 & ISSN 1410-3249 \\
\hline
\end{tabular}




\section{KATA SAMBUTAN}

Kami panjatkan rasa syukur kepada Tuhan Yang Maha Esa atas terbitnya Kajian Ekonomi dan Keuangan edisi ini ke hadapan pembaca sekalian. Pada edisi ini, kami menyajikan berbagai topik yang berkaitan dengan analisis dan dampak kebijakan publik di bidang ekonomi dan keuangan negara.

Kajian pada volume kali ini diisi oleh berbagai topik tulisan yaitu Potensi Penerimaan Pajak Dari Underground Economy di Indonesia; Dampak Volatilitas Harga Minyak di Indonesia Terhadap Penyesuaian Keseimbangan Fiskal; Analisis Permasalahan Pembiayaan UMKM di Indonesia; Analisis Kesinambungan Transaksi Berjalan Indonesia : 1980-2010; dan Perkembangan FDI ke Indonesia dan Langkah Kebijakan yang Diperlukan. Adapun para penulis yang berkontribusi pada penerbitan kali ini yaitu M. Afdi Nizar, Kuntarto Purnomo, Mahpud Sujai, R. Nurhidajat, Rudi Handoko, dan Suparman Zen Kemu.

Demikianlah kata pengantar yang dapat kami sampaikan. Ibarat peribahasa tiada gading yang tak retak, maka kami menyadari kajian ini tentunya masih terdapat kekurangan baik yang disengaja maupun yang tidak kami sengaja. Oleh karena itu, kami mengharapkan masukan dari para pembaca guna perbaikan di masa yang akan datang. Selanjutnya, kami berharap jurnal ini dapat memberikan manfaat kepada para pembaca sekalian. Selamat membaca!

Jakarta, 2011

Dewan Redaksi 


\section{DAFTAR ISI}

Cover

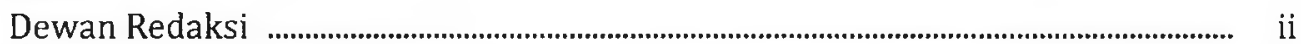

Kata Sambutan ...................................................................................................................... ii

Daftar Isi ............................................................................................................... v

Daftar Tabel ............................................................................................................................ vi

Daftar Gambar ....................................................................................................................................... vii

Kumpulan Abstraksi ................................................................................................................................ ix

\section{POTENSI PENERIMAAN PAJAK DARI UNDERGROUND ECONOMY}

DI INDONESIA

Oleh: M. Afdi Nizar dan Kuntarto Purnomo

DAMPAK VOLATILITAS HARGA MINYAK DI INDONESIA TERHADAP PENYESUAIAN KESEIMBANGAN FISKAL

Oleh: Mahpud Sujai

ANALISIS PERMASALAHAN PEMBIAYAAN UMKM DI INDONESIA

Oleh: R. Nurhidajat

ANALISIS KESINAMBUNGAN TRANSAKSI BERJALAN

INDONESIA : 1980-2010

Oleh: Rudi Handoko

PERKEMBANGAN FDI KE INDONESIA DAN LANGKAH

KEBIJAKAN YANG DIPERLUKAN

Oleh: Suparman Zen Kemu 


\section{DAFTAR TABEL}

\section{POTENSI PENERIMAAN PAJAK DARI UNDERGROUND ECONOMY DI INDONESIA}

Tabel 2.1. Klasifikasi Underground Economy ................................................................... 11

Tabel 3.1. Hasil Pengujian Akar Unit ............................................................................. 17

Tabel 3.2. Hasil Estimasi Permintaan Uang Kartal .................................................... 17

Tabel 3.3. Uang Kartal Underground Economy ......................................................... 20

Tabel 3.4. Underground Economy di Indonesia, Tahun 2000 - 2009 ................... 21

Tabel 3.5. Lapisan Kena Pajak dan Tarif Pajak .............................................................. 22

Tabel 3.6. Potensi Pajak atas Underground Economy ................................................... 23

Tabel 3.7. Hasil Estimasi Pengaruh Tarif Pajak Terhadap Underground Economy ............................................................................. 25

\section{DAMPAK VOLATILITAS HARGA MINYAK DI INDONESIA TERHADAP} PENYESUAIAN KESEIMBANGAN FISKAL.

Tabel 4.1. Hasil Perhitungan Output Potensial dan Output Gap ........................... 50

\section{ANALISIS PERMASALAHAN PEMBIAYAAN UMKM DI INDONESIA}

Tabel 5.1. Jumlah Usaha Yang Tidak Berbadan Hukum Menurut Lapangan Usaha 1998-2004

Tabel 5.2 Kontribusi Usaha Mikro Kecil Menengah dan Besar Terhadap PDB, Harga Konstan 2000, Tahun 2005-2009

Tabel 6.1. Pertumbuhan Kredit Usaha Kecil Oleh Perbankan 60

Tabel 6.2. Alokasi Kredit Untuk Umkm Dan NPL UMKM

Tahun 2006 - 2010 61

Tabel 6.3. Rasio UKM Tak Berbadan Hukum terhadap Total UKM 63

\section{ANALISIS KESINAMBUNGAN TRANSAKSI BERJALAN INDONESIA : 1980-2010}

Tabel 4.1. Rasio Utang Luar Negeri Jangka Panjang $\left(n^{*}\right)$ 81

Tabel 4.2. Indikator Kesinambungan Transaksi Berjalan

\section{PERKEMBANGAN FDI KE INDONESIA DAN LANGKAH}

\section{KEBIJAKAN YANG DIPERLUKAN}

Tabel 2.1. Foreign Direct Investment ke Indonesia

Dari Negara-Negara Non ASEAN Per sektor (US\$ juta) ......................... 100

Tabel 2.2 Foreign Direct Investment ke Indonesia Dari Negara-negara non ASEAN (US\$ juta) ................................................. 101

Tabel 2.3. Foreign Direct Investment ke Indonesia dari Negara-negara ASEAN per sektor (US\$ juta) .................................... 102

Tabel 2.4. Foreign Direct Investment ke Indonesia Dari Negara-negara ASEAN (US\$ juta) 102 


\section{DAFTAR GAMBAR}

\section{DAMPAK VOLATILITAS HARGA MINYAK DI INDONESIA TERHADAP PENYESUAIAN KESEIMBANGAN FISKAL}

Gambar 2.1. Hubungan Antara Berbagai Keseimbangan

Grafik 3.1. Pertumbuhan Domestik Bruto Indonesia

Tahun 1991-2010

Grafik 3.2. Penerimaan Negara Dalam Persentase PDB

Tahun 1991-2010

Grafik 3.3. Belanja Pemerintah Pusat Tahun 1991-2010

Grafik 3.4. Belanja Pemerintah Pusat Persentase Terhadap PDB

Tahun 1991-2010

Grafik 3.5. Perkembangan Harga Minyak Indonesia Tahun 1991-2010 .............. 47

Grafik 3.6. Produksi Minyak Indonesia Tahun 1991-2010 ..................................... 48

Grafik 4.1 Dampak Output Gap Terhadap CAB (Linear Trend) .............................. 49

Grafik 4.2. Dampak Output Gap Terhadap CAB(HP Filter) ....................................... 49

Grafik 4.3. Hasil Perhitungan Keseimbangan Aktual dan Potensial ....................... 50

\section{ANALISIS PERMASALAHAN PEMBIAYAAN UMKM DI INDONESIA}

Gambar 5.1. Jumlah Unit Usaha Tahun 2009 56

Gambar 5.2. Jumlah Tenaga Kerja Berdasarkan Usaha Tahun 2009 58

\section{ANALISIS KESINAMBUNGAN TRANSAKSI BERJALAN INDONESIA : 1980-2010}

Gambar 3.1. Neraca Pembayaran Indonesia 1980 - 2010 (US\$ juta) 76

Gambar3.2. Komponen Transaksi Berjalan 1980 - 2010 (US\$ juta)

Gambar 4.1 Transaksi Berjalan dan Penarikan Pinjaman Luar Negeri Pemerintah 1980 - 2010 (US\$ juta)

Gambar 4.2 Transaksi Berjalan dan Stok Utang Luar Negeri

Gambar 4.3 Rasio Pembayaran Utang Terhadap Ekspor 79

(Debt Service Ratio) 1980 - 2010 80

Gambar 4.4 Ekspor Barang dan Jasa (\% PDB) 1980 - 2010

Gambar 4.5 Neraca Pembayaran, Nilai Tukar Riil Rp/USD dan Cadangan Devisa 1980-2010

Gambar 4.6 Celah Tabungan-Investasi dan Transaksi Berjalan 1990-2010 (miliar Rp) 86

Gambar 4.7 Surplus (Defisit) APBN dan Transaksi Berjalan 1980 - 2010 (\% dari PDB)

Gambar 4.8 Pertumbuhan Ekonomi dan Transaksi Berjalan 1980-2010 89 Gambar 4.9 Transaksi Berjalan dan Investasi 1980 - 2010 (US\$ juta) 


\section{PERKEMBANGAN FDI KE INDONESIA DAN LANGKAH}

\section{KEBIJAKAN YANG DIPERLUKAN}

Grafik 3.1. FDI Dari Negara-Negara Non ASEAN Menurut

Sektor Ekonomi ............................................................................................... 103

Grafik 3.2. FDI Negara-Negara Non ASEN Menurut Negara Asal ............................ 104

Grafik 3.3. FDI Menurut Sektor Ekonomi (ASEAN) ................................................... 105

Grafik 3.4. FDI Menurut Negara Asal (ASEAN) .............................................................. 106 


\begin{tabular}{|c|}
\hline $\begin{array}{l}\text { MAJALAH KAJIAN EKONOMI DAN KEUANGAN } \\
\text { ISSN 1410-3249 } \\
\text { KEK Terakreditasi B } \\
\text { (No. Akreditasi : 306/AU2/P2MBI/08/2010) } \\
\text { Volume 15 Nomor 2 Tahun 2011 } \\
\end{array}$ \\
\hline $\begin{array}{l}\text { Keywords used are free terms. Abstracts can be reproduced without } \\
\text { permission or charge. }\end{array}$ \\
\hline ABSTRAKSI \\
\hline $\begin{array}{l}\text { Nizar, M. Afdi, dan Purnomo, Kuntarto, et. al. (Kementerian Keuangan) } \\
\text { Potensi Penerimaan Pajak Dari Underground Economy di Indonesia } \\
\text { Kajian Ekonomi dan Keuangan Volume } 15 \text { Nomor } 2 \text { Tahun 2011, halaman } \\
\text { 1-36 }\end{array}$ \\
\hline $\begin{array}{l}\text { This study aims to estimate the size of underground economy activities in } \\
\text { Indonesia. Based on the results of these estimates, further calculated the } \\
\text { potential tax loss due to the existence of underground economy activities. } \\
\text { This study was conducted using quantitative approaches, namely currency } \\
\text { demand model which is estimated by ordinary least square (OLS) method. By } \\
\text { using time series (quarterly) data period } 2000-2009 \text { we found that the size } \\
\text { of underground economy is about Rp164, } 4 \text { trillion per year on average, } \\
\text { equivalent to } 6 \% \text { of GDP. Meanwhile, the potential tax loss due to the activity } \\
\text { estimated at Rp20,6 trillion on average per year, or approximately } 0.69 \% \text { of } \\
\text { GDP. }\end{array}$ \\
\hline $\begin{array}{l}\text { Keywords : economic growth, official economy, underground economy, tax } \\
\text { rate. }\end{array}$ \\
\hline $\begin{array}{l}\text { Sujai, Mahpud, et. al. (Badan Kebijakan Fiskal, Kementerian Keuangan) } \\
\text { Dampak Volatilitas Harga Minyak di Indonesia Terhadap Penyesuaian } \\
\text { Keseimbangan Fiskal }\end{array}$ \\
\hline $\begin{array}{l}\text { Kajian Ekonomi dan Keuangan Volume } 15 \text { Nomor } 2 \text { Tahun 2011, halaman } \\
37-52\end{array}$ \\
\hline $\begin{array}{l}\text { This paper is intended to analyze the effect of oil price changes on potential } \\
\text { output and actual output in the state budget cycle and identifies the output } \\
\text { gap which is the difference between potential output and actual output. The } \\
\text { research methodology uses a quantitative approach to analyze problems that } \\
\text { occur related to the impact of oil price changes to the state budget cycle. } \\
\text { Data analysis was carried out through the approach cyclically adjusted fiscal } \\
\text { balance with a simplified approach. This research identified that the } \\
\text { potential output is likely to continue increasing in line with Indonesia's oil }\end{array}$ \\
\hline
\end{tabular}




\begin{tabular}{|c|}
\hline $\begin{array}{l}\text { MAJALAH KAJIAN EKONOMI DAN KEUANGAN } \\
\text { ISSN 1410-3249 } \\
\text { KEK Terakreditasi B } \\
\text { (No. Akreditasi : 306/AU2/P2MBI/08/2010) } \\
\text { Volume } 15 \text { Nomor } 2 \text { Tahun 2011 }\end{array}$ \\
\hline $\begin{array}{l}\text { Keywords used are free terms. Abstracts can be reproduced without } \\
\text { permission or charge. }\end{array}$ \\
\hline ABSTRAKSI \\
\hline $\begin{array}{l}\text { price trends which is continue to rise following the world oil price } \\
\text { movements. In calculating the output gap using a linear trend and HP filter, } \\
\text { the result is fluctuating depend on the percentage changes in both potential } \\
\text { output and actual output. This paper concludes that Indonesian oil price } \\
\text { (ICP) has a significant impact on changes in the state budget cycle. If oil } \\
\text { prices rise, the output gap between potential output and actual output is } \\
\text { greater, and vice versa. This will make the budget vulnerable to shock that } \\
\text { occurs as an external influence. } \\
\text { Keywords: Fiscal Balance, Oil prices, Output Gap, PDB }\end{array}$ \\
\hline $\begin{array}{l}\text { Nurhidajat, R, et. al. [Badan Kebijakan Fiskal, Kementerian Keuangan] } \\
\text { Analisis Permasalahan Pembiayaan UMKM di Indonesia } \\
\text { Kajian Ekonomi dan Keuangan Volume } 15 \text { Nomor } 2 \text { Tahun 2011, halaman } \\
\text { 53-68 }\end{array}$ \\
\hline $\begin{array}{l}\text { Micro small and medium enterprises (SMEs) have a strategic role in } \\
\text { Indonesia's economy. Therefore, this sector requires adequate financial } \\
\text { support. By using Granger causality test, this study show that credit to small } \\
\text { businesses caused economic growth. The data used in this study from March } \\
2001 \text { to December 2009. Data obtained through the Central Bureau of } \\
\text { Statistics, Ministry of Cooperatives and SMEs, as well as Bank Indonesia. This } \\
\text { study also found evidence that government-owned banks have been allocated } \\
\text { large funds to assist SMEs. However, the credit growth is still less than the } \\
\text { credit growth of the foreign and joint banks which are expanding its business } \\
\text { into the SME sector. The expansion of foreign and joint banks in the SME } \\
\text { sector can be seen from the high growth in credit to this sector. In addition, } \\
\text { this study analyzed alternative solutions for financing SMEs. The Government } \\
\text { needs to promote microfinance institutions as an alternative solution for SME } \\
\text { financing. }\end{array}$ \\
\hline Keywords: SMEs, credit growth, micro finance institutions, joint banks \\
\hline
\end{tabular}




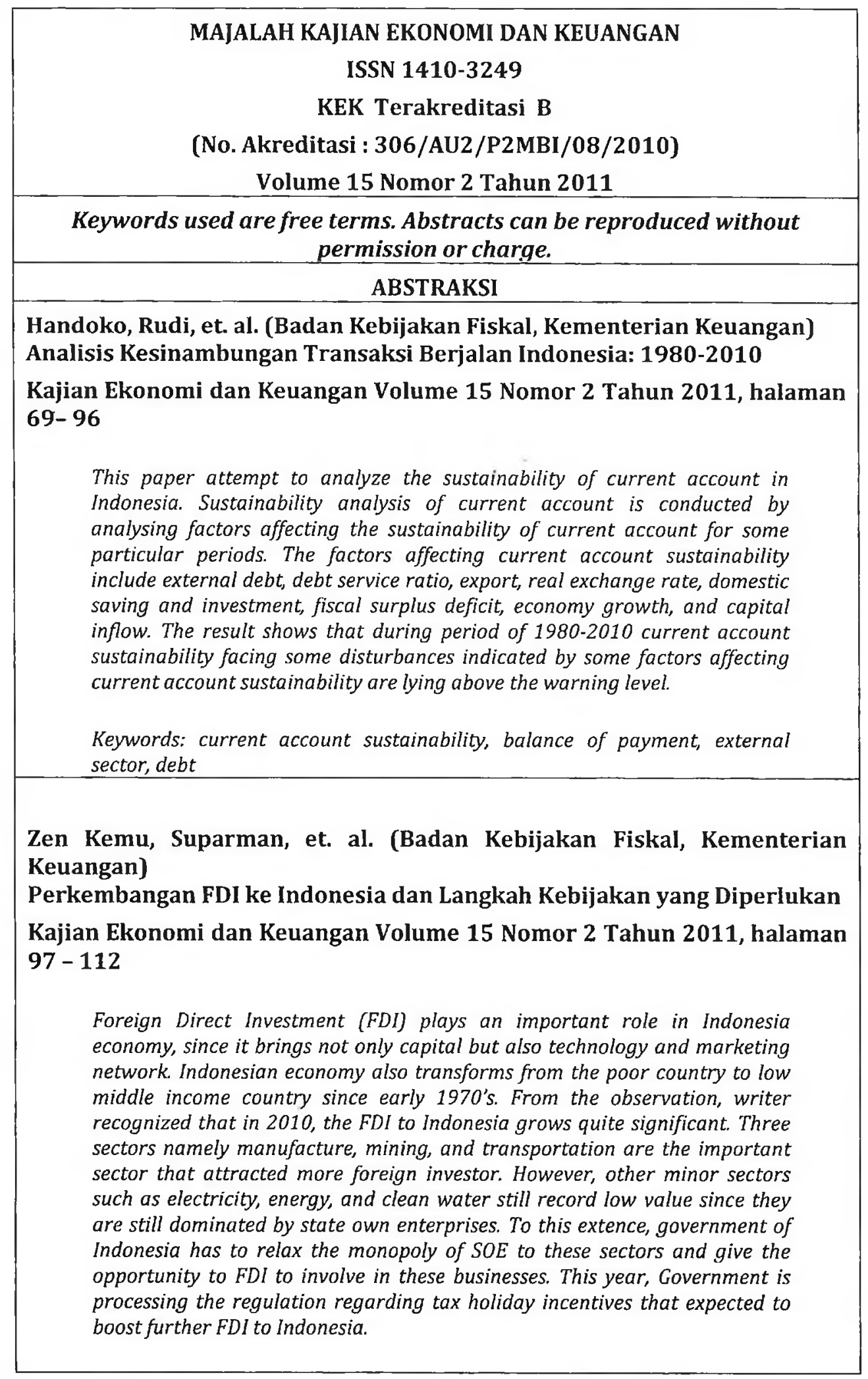




\begin{tabular}{|c|}
\hline MAJALAH KAJIAN EKONOMI DAN KEUANGAN \\
ISSN 1410-3249 \\
KEK Terakreditasi B \\
(No. Akreditasi : 306/AU2/P2MBI/08/2010) \\
Volume 15 Nomor 2 Tahun 2011 \\
\hline Keywords used are free terms. Abstracts can be reproduced without \\
permission or charge. \\
\hline ABSTRAKSI \\
\hline Keywords: FDI, Indonesian Economy, Investor, Sectors \\
\hline
\end{tabular}




\title{
PERKEMBANGAN FDI KE INDONESIA DAN LANGKAH KEBIJAKAN YANG DIPERLUKAN
}

\author{
Oleh: \\ Suparman Zen Kemu ${ }^{1}$
}

\begin{abstract}
Foreign Direct Investment (FDI) plays an important role in Indonesia economy, since it brings not only capital but also technology and marketing network. Indonesian economy also transforms from the poor country to low middle income country since early 1970's. From the observation, writer recognized that in 2010, the FDI to Indonesia grows quite significant. Three sectors namely manufacture, mining, and transportation are the important sector that attracted more foreign investor. However, other minor sectors such as electricity, energy, and clean water still record low value since they are still dominated by state own enterprises. To this extence, government of Indonesia has to relax the monopoly of SOE to these sectors and give the opportunity to FDI to involve in these businesses. This year, Government is processing the regulation regarding tax holiday incentives that expected to boost further FDI to Indonesia.
\end{abstract}

Keywords : FDI, Indonesian Economy, Investor, Sectors

\section{PENDAHULUAN}

Tidak bisa disangkal kalau kemajuan ekonomi Indonesia saat ini tak lepas dari peran penanaman modal asing (FDI) yang mulai hadir sejak dibukanya Indonesia terhadap modal asing pada tahun akhir tahun 1960-an. ${ }^{2}$ Investor asing ini membawa tidak hanya modal, tapi juga teknologi dan networking pemasaran produknya. Sejak itu, aliran masuk FDI ke Indonesia mengalami pertumbuhan yang sangat signifikan dan berkontribusi cukup besar terhadap pertumbuhan ekonomi Indonesia selama empat dasa warsa belakangan ini.

Kalau pada akhir tahun 1960-an tersebut Indonesia termasuk tiga bangsa termiskin didunia ${ }^{3}$, maka pada tahun 2010 Indonesia sudah menjadi bangsa yang berada pada level low middle income country bahkan sudah mendekati status

\footnotetext{
1 Peneliti pada Pusat Kebijakan Kerja Sama Regional dan Bilateral.

${ }^{2}$ Undang Undang Penanaman Modal Asing no.1 tahun 1967 tentang Penanaman Modal Asing.

${ }^{3}$ Dua Negara lainnya adalah Negara-negara di Benua Afrika.
} 
sebagai high middle income country, ${ }^{4}$ dengan pendapatan per kapita pada kisaran US $\$ 3,000$.

Berkaitan dengan fenomena ini, penulis tertarik untuk melihat perkembangan aliran masuk FDI ke Indonesia selama enam tahun terakhir yang penulis anggap sebagai periode kebangkitan FDI ke Indonesia.

Tulisan ini dibagi menurut aliran masuk FDI menurut Negara asal dan sektor usaha, juga berdasarkan FDI dari negara-negara non ASEAN dan NegaranegaraASEAN. 5

\subsection{Tujuan Penulisan}

Tulisan ini bertujuan untuk melakukan pengamatan terhadap perkembangan aliran masuk FDI ke Indonesia pada enam tahun terakhir, yaitu dari tahun 2005 sampai tahun 2010. Beberapa hal yang menjadi sorotan adalah Negara asal FDI dan sektor-sektor usahanya. Beberapa faktor yang bersifat kualitatif seperti kebijakan perpajakan, pengaturan, serta infrastruktur juga diamati pada tulisan ini.

\subsection{Metodologi Penulisan}

Data dikumpulkan dari berbagai sumber seperti Bank Indonesia, BKPM, BPS dan juga dari website. Tulisan ini bersifat analisis deskriptif menggunakan pendekatan statistik, yaitu analisa trend.

\subsection{Pembatasan Masalah}

Tulisan ini fokus pada perkembangan enam tahun terakhir yang penulis anggap bisa mewakili gambaran perkembangan aliran masuk FDI ke Indonesia yang paling up-to-date dan merupakan periode kebangkitan FDI ke Indonesia paska krisis ekonomi Indonesia 1998.

\subsection{Manfaat Penulisan}

Hasil penulisan diharapkan menjadi acuan bagi pembuat kebijakan dan pihak lain yang berkepentingan dalam melakukan penelitian lebih lanjut.

\subsection{Pengertian Penanaman Modal Asing (FDI)}

Menurut UU no.25 tahun 2007 tentang Penanaman Modal disebutkan bahwa Penanaman Modal adalah segala bentuk kegiatan menanam modal, baik oleh penanam modal dalam negeri maupun penanam modal asing untuk melakukan usaha di wilayah Negara Republik Indonesia. Sedangkan Penanaman Modal Asing adalah kegiatan menanam modal untuk melakukan usaha di wilayah negara

\footnotetext{
${ }^{4}$ Menurut Bank Dunia, suatu Negara bisa disebut sebagai Negara High Middle Income Country apabila sudah mecapai income per capita US $\$ 5,000$.

5 Dengan pembedaan ini, maka FDI dari negara-negara ASEAN mendapat sorotan tersendiri dan lebih memberi wama kepada FDI yang masuk ke Indonesia.
} 
Republik Indonesia yang dilakukan oleh penanam modal asing, baik yang menggunakan modal asing sepenuhnya maupun yang berpatungan dengan penanam modal dalam negeri.

Menurut Michael P. Todaro, pengertian FDI adalah "The international flow of financial resources takes two main forms: Private foreign investment, mostly foreign direct investment (FDI) by large multinational or trans national corporation with headquarters in the developed nations along with flows of financial capital by private international banks, and public development assistance (foreign aid), from both individual national governments and multinational donor agencies.

Few developments played as critical a role in the extraordinary growth of international trade and capital flows during the past three decades as the rise of the Multinational Corporation (MNC). An MNC is most simply defined as a corporation or enterprise that conducts and controls productive activities in more than one country. These huge business firms, mostly from North America, Europe, and Japan, present a unique opportunity and a host of serious problems for many developing countries in which they operate" (Todaro, Michael P 1997 p-527).

\section{GAMBARAN UMUM}

Beberapa sektor yang diminati oleh investor asing non ASEAN dalam melakukan investasinya ke Indonesia adalah: Pertama sektor manufaktur atau pengolahan yang dalam kurun waktu 6 tahun (2005-2010) porsinya 37,95\% dari total. Kedua adalah sektor pertambangan dan penggalian sesuai dengan kondisi Indonesia yang merupakan Negara dengan sumber kekayaan alam (tambang) yang berlimpah, porsinya 21,4\%. Sedangkan sektor ketiga adalah transportasi, pergudangan, dan komunikasi, porsinya $12,51 \%$. Sektor keempat adalah Lembaga Perantara Keuangan, porsinya 11,95\%. Sedangkan sektor kelima adalah perdagangan besar dan eceran, perbaikan kendaraan bermotor, dan barang-barang rumah tangga, porsinya 9,23\%. Itulah lima besar sektor ekonomi yang diminati oleh investor asing non ASEAN dalam menanamkan modalnya di Indonesia. Peranan kelima sektor ini sangat dominan karena meliputi 93,04\% dari total.

Mengamati perkembangan per tahun, terlihat bahwa pada dua tahun yaitu 2006 dan 2009 terjadi penurunan FDI dari negara-negara non ASEAN ke Indonesia. Pada tahun 2006 nilai FDI turun menjadi US\$ 4,914 juta dari US\$ 8,336 juta pada tahun 2005, atau terjadi penurunan sebesar $41,05 \%$. Sedangkan pada tahun 2009 , nilai FDI turun menjadi US $\$ 4,877$ juta dari posisi tahun 2008 yang mencapai US $\$$ 9,318 juta, atau terjadi penurunan sebesar $47,66 \%$. 
Tabel 2.1.

Foreign Direct Investment ke Indonesia Dari Negara-Negara Non ASEAN Per sektor (US\$ juta)

\begin{tabular}{|c|c|c|c|c|c|c|c|c|c|}
\hline NO & SEKTOR EKONOMI & 2005 & 2006 & 2007 & 2008 & 2009 & 2010 & Jumlah & $\%$ \\
\hline 1 & Industri Pengolahan & 5,265 & 1,691 & 2,412 & 2,323 & 1,574 & 4,612 & 17,877 & $37.95 \%$ \\
\hline 2 & $\begin{array}{l}\text { Pertambangan dan } \\
\text { Penggalian }\end{array}$ & 1,226 & 322 & 1,905 & 3,609 & 1,301 & 1,718 & 10,081 & $21.40 \%$ \\
\hline 3 & $\begin{array}{l}\text { Transportasi, } \\
\text { Pergudangan, dan } \\
\text { Komunikasi }\end{array}$ & 384 & 592 & 598 & 133 & 1,800 & 2,386 & 5,893 & $12.51 \%$ \\
\hline 4 & $\begin{array}{l}\text { Lembaga Perantara } \\
\text { Keuangan }\end{array}$ & 780 & 1,028 & 1,338 & 1,926 & 148 & 408 & 5,628 & $11.95 \%$ \\
\hline 5 & $\begin{array}{l}\text { Perdagangan Besar } \\
\text { dan Eceran; Perbaikan } \\
\text { Kendaraan Bermotor; } \\
\text { Barang-Barang Rumab } \\
\text { Tangga }\end{array}$ & 60 & 375 & 214 & 1,160 & 74 & 2,465 & 4,348 & $9.23 \%$ \\
\hline 6 & $\begin{array}{l}\text { Pertanian, Perburuan, } \\
\text { dan Kehutanan }\end{array}$ & 2 & 225 & 285 & 197 & -52 & 267 & 924 & $1.96 \%$ \\
\hline 7 & Konstruksí & 130 & 85 & 196 & 24 & 6 & -49 & 392 & $0.83 \%$ \\
\hline 8 & Listrik, Gas, dan Air & 163 & -1 & -61 & -56 & 53 & 204 & 302 & $0.64 \%$ \\
\hline 9 & Perikanan & 9 & 4 & 19 & -24 & 9 & 50 & 67 & $0.14 \%$ \\
\hline 10 & Hotel dan Restoran & $\cdot$ & 7 & -10 & 16 & - & 1 & 14 & $0.03 \%$ \\
\hline 11 & $\begin{array}{l}\text { Real Estate, } \\
\text { Persewaan, dan Jasa } \\
\text { Bisnis }\end{array}$ & 17 & -14 & -4 & -201 & -25 & 22 & -205 & $-0.44 \%$ \\
\hline 12 & Lainnya & 301 & 599 & 37 & 212 & -11 & 652 & 1,790 & $3.80 \%$ \\
\hline 13 & Jumlah & 8,336 & 4,914 & 6,928 & 9,318 & 4,877 & 12,736 & 47,109 & $100.00 \%$ \\
\hline
\end{tabular}

Sumber: Bank Indonesia.

Negara-negara non ASEAN yang menonjol peranannya dalam melakukan investasi ke Indonesia selama 6 tahun terakhir adalah Jepang $(20,12 \%)$ dari total, Amerika Serikat (12,01\%), dan Belanda 7,01\%. Beberapa Negara lain yang juga cukup menonjol perannya adalah Australia (4,86\%), RR China (3,72\%), Prancis $(3,49 \%)$, Korea Selatan (3\%), Luxemburg, dan Inggris masing-masing $3 \%$ dan $2,59 \%$.

Mengamati perkembangan FDI dari negara-negara non ASEAN pada tahun 2010 , beberapa Negara mengalami peningkatan yang signifikan dibandingkan ratarata nilai investasi mereka 5 tahun sebelumnya yaitu: Jepang dari rata-rata US\$ 1,153 juta menjadi US 3,712 juta atau meningkat sebesar $222 \%$. Amerika Serikat mengalami penurunan sebesar $-54 \%$. Belanda juga mengalami penurunan sebesar $-174 \%$. Australia meningkat cukup signifikan yaitu 221\%. RRC meningkat sebesar $13 \%$. Prancis mengalami penurunan sebesar $-71 \%$. Korea Selatan meningkat sebesar 58\%. Luxemburg meningkat dengan angka yang fantastis yaitu $983 \%$. Inggris juga meningkat tajam yaitu sebesar 131\%. Secara keseluruhan, FDI ke 
Indonesia pada tahun 2010 meningkat sebesar 85\% dari rata-rata 5 tahun sebelumnya.

Tabel 2.2.

Foreign Direct Investment ke Indonesia Dari Negara-negara non ASEAN (US\$ juta)

\begin{tabular}{|c|c|c|c|c|c|c|c|c|c|c|c|}
\hline \multirow[b]{2}{*}{ No. } & \multirow[b]{2}{*}{ Negara } & \multicolumn{8}{|c|}{ Tahun } & \multirow[b]{2}{*}{ Jumlah } & \multirow[b]{2}{*}{ Persentase } \\
\hline & & 2005 & 2006 & 2007 & 2008 & 2009 & $\begin{array}{l}\text { Rata } \\
\text { Rata }\end{array}$ & 2010 & $\Delta$ & & \\
\hline 1 & Jepang & 1,543 & 1,057 & 1.125 & 1,144 & 896 & 1,153 & 3,712 & $222 \%$ & 9,477 & $20.12 \%$ \\
\hline 2 & Amerika Serikat & 3,441 & -549 & 1,093 & 1,040 & 159 & 1,037 & 472 & $-54 \%$ & 5,656 & $12.01 \%$ \\
\hline 3 & Belanda & 673 & 1,340 & 1,750 & 755 & -646 & 774 & -570 & $-174 \%$ & 3,302 & $7.01 \%$ \\
\hline 4 & Australia & 56 & 366 & 309 & 399 & 263 & 279 & 895 & $221 \%$ & 2.288 & $4.86 \%$ \\
\hline 5 & RRC & 299 & 124 & 117 & 531 & 359 & 286 & 323 & $13 \%$ & 1,753 & $3.72 \%$ \\
\hline 6 & Prancis & 280 & 213 & 383 & 418 & 257 & 310 & 91 & $.71 \%$ & 1,642 & $3.49 \%$ \\
\hline 7 & Korea Selatan & 239 & 317 & 251 & 186 & 81 & 215 & 340 & $58 \%$ & 1,414 & $3.00 \%$ \\
\hline 8 & Luxemburg & - & - & - & 4 & 382 & 77 & 836 & $983 \%$ & 1,222 & $2.59 \%$ \\
\hline 9 & lnggris & 50 & 31 & -52 & 291 & 402 & 144 & 333 & $131 \%$ & 1,055 & $2.24 \%$ \\
\hline 10 & Jerman & 436 & 425 & 335 & 199 & -89 & 261 & -825 & $.416 \%$ & 481 & $1.02 \%$ \\
\hline 11 & Hong Kong & 52 & 118 & 115 & 45 & 59 & 78 & 86 & $11 \%$ & 475 & $1.01 \%$ \\
\hline 12 & India & 1 & 1 & -345 & 1 & 6 & .67 & 3 & $104 \%$ & -333 & $-0.71 \%$ \\
\hline 13 & Taiwan & 38 & 57 & 77 & 16 & 16 & 41 & 25 & $-39 \%$ & 229 & $0.49 \%$ \\
\hline 14 & Lain-lain*/ & 7,108 & 3,500 & 5,158 & 5,029 & 2,145 & $25 \%$ & 5,721 & $25 \%$ & 20,826 & $42.08 \%$ \\
\hline 15 & Jumlah & 8,336 & 4,914 & 6,928 & 9,318 & 4,877 & $85 \%$ & 12,736 & $85 \%$ & 47,109 & $100 \%$ \\
\hline
\end{tabular}

Sumber: Bank Indonesia

FDI dari Negara-negara ASEAN terkonsentrasi pada sektor industri pengolahan (manufacturing) yaitu $74,42 \%$ dari total. Berikutnya adalah pada sektor pertambangan dan penggalian (16,44\%). Sedangkan sektor ketiga terbesar adalah pertanian, perburuan, dan kehutanan $(8,43 \%)$.

Dari enam sektor yang tercantum pada tabel 3.3 , tiga sektor yaitu konstruksi, perikanan, listrik, gas dan air, merupakan sektor yang nilainya sangat rendah yaitu masing-masing $0,8 \%, 0,12 \%$ dan minus $0,22 \%$, atau totalnya hanya $0,70 \%$.

Kalau dilihat perkembangan per tahun, sebagaimana pola FDI negara non ASEAN yang telah diuraikan sebelumnya, pada tahun 2006 dan 2009 terjadi penurunan nilai FDI Negara-negara ASEAN ke Indonesia. Pada tahun 2006 terjadi penurunan dari US\$ 683 juta menjadi US\$ 385 juta atau turun sebesar 43,63\%. Sedangkan pada tahun 2009 , terjadi penurunan dari US\$1,658 juta menjadi US\$ 762 juta atau turun sebesar $54,04 \%$. 
Tabel 2.3.

Foreign Direct Investment ke Indonesia dari Negara-negara ASEAN per sektor (US\$ juta)

\begin{tabular}{|c|c|c|c|c|c|c|c|c|c|}
\hline No & Sektor/Negara Asal & 2005 & 2006 & 2007 & 2008 & 2009 & 2010 & Jumlah & Persentase \\
\hline 1 & Industri Pengolahan & 627 & 423 & 398 & 989 & 532 & 1,390 & 4,359 & $74.42 \%$ \\
\hline 2 & $\begin{array}{l}\text { Pertambangan dan } \\
\text { Penggalian }\end{array}$ & 32 & -142 & 107 & 608 & 142 & 216 & 963 & $16.44 \%$ \\
\hline 3 & $\begin{array}{l}\text { Pertanian, Perburuan, dan } \\
\text { Kehutanan }\end{array}$ & 22 & 51 & 10 & 105 & 63 & 243 & 494 & $8.43 \%$ \\
\hline 4 & Konstruksi & 2 & 34 & 24 & 14 & -4 & 23 & 47 & $0.80 \%$ \\
\hline 5 & Perikanan & - & - & - & 8 & -1 & & 7 & $0.12 \%$ \\
\hline 6 & Listrik, Gas, dan Air & - & 19 & - & 66 & 30 & 4 & -13 & $-0.22 \%$ \\
\hline 7 & JUMLAH & 683 & 385 & 539 & 1,658 & 762 & 1,830 & 5,857 & $100.00 \%$ \\
\hline
\end{tabular}

Sumber: Bank Indonesia

Dari 9 negara ASEAN hanya 3 negara yaitu Singapura, Malaysia dan Thailand yang FDl nya bisa diamati, sedangkan 6 negara ASEAN yang lain kontribusinya belum terlihat, atau sangat kecil. Dari ketiga Negara ini, Singapura mendominasi FDI ke Indonesia yaitu 78,9\% dengan jumlah FDI selama 6 tahun terakhir sebesar US $\$ 4,601$ juta. Berikutnya adalah Malaysia dengan nilai US $\$ 1,042$ juta atau $17,9 \%$. Sedangkan Thailand berada pada urutan ketiga dengan nilai US\$ 192 juta atau $3,3 \%$.

Pada tahun 2010, terjadi peningkatan aliran masuk FDI dari masing-masing Negara dibandingkan dengan rata-rata FDI 5 tahun terakhir (2005-2009). Singapura mengalami peningkatan sebesar $52,4 \%$, Malaysia $859,4 \%$, dan Thailand sebesar 132,8\%. Sedangkan secara keseluruhan, pada tahun 2010 terjadi peningkatan sebesar $126,8 \%$.

Tabel 2.4.

Foreign Direct Investment ke Indonesia Dari Negara-negara ASEAN (US\$ juta)

\begin{tabular}{|l|l|c|c|c|c|c|cc|c|c|c|}
\hline No & Sektor/Negara Asal & 2005 & 2006 & 2007 & 2008 & 2009 & $\begin{array}{l}\text { Rata- } \\
\text { rata }\end{array}$ & 2010 & $\Delta$ & ILH & $\%$ \\
\hline 1 & Singapura & 623 & 352 & 483 & 1,582 & 486 & 705 & 1,075 & $52.4 \%$ & 4,601 & $78.9 \%$ \\
\hline 2 & Malaysia & 60 & 31 & 15 & 10 & 241 & 71 & 685 & $859.4 \%$ & 1,042 & $17.9 \%$ \\
\hline 3 & Thailand & 1 & 2 & 29 & 65 & 34 & 26 & 61 & $132.8 \%$ & 192 & $3.3 \%$ \\
\hline & JUMLAH & 684 & 385 & 527 & 1,657 & 761 & 803 & 1,821 & $126,8 \%$ & 5,835 & $100.0 \%$ \\
\hline
\end{tabular}

Sumber: Bank Indonesia 


\section{ANALISIS}

Pada bab ini penulis melakukan analisa trend (kecenderungan arah) dengan menggunakan grafik. Disamping itu Analisis dipertajam dengan mencari penyebab dari terjadinya trend tersebut.

Pada grafik 3.1 terlihat bahwa 3 sektor utama yaitu pengolahan, pertambangan dan perdagangan mengalami kecenderungan meningkat, walau sektor pengolahan belum bisa menyamai nilai investasi pada tahun 2005. Memang krisis ekonomi yang terjadi pada 2005 (krisis mini) dan krisis global pada tahun 2008 memberikan dampak penurunan pada arus masuk nilai FDI di tahun 2006 dan tahun 2009 (lag setahun). Namun untuk tiga sektor yaitu pengolahan, perdagangan, dan transportasi pada tahun 2010 nilainya meningkat dengan tajam. Bahkan untuk sektor manufaktur nilainya sudah mendekati tahun 2005 yang merupakan rekor tertinggi.

Grafik 3.1.

FDI Dari Negara-Negara Non ASEAN Menurut Sektor Ekonomi

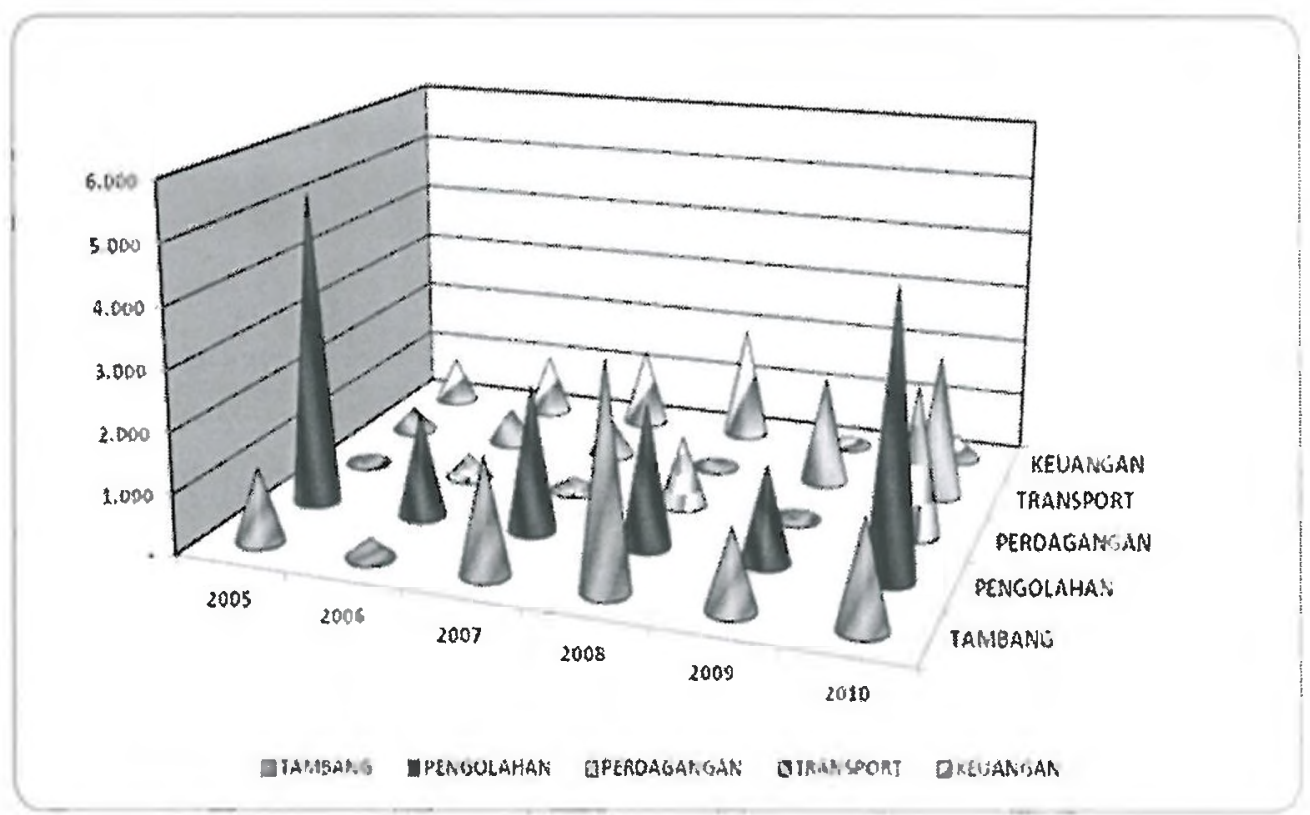

Sumber: Bank Indonesia

Beberapa hal yang menarik untuk dilihat pada grafik 3.2 adalah: Terjadi peningkatan yang pesat dari nilai FDI Jepang pada tahun 2010 yaitu mencapai US\$ 3,712 juta. Hal ini merupakan suatu pertanda baik kembalinya Jepang menjadi Negara utama dalam melakukan FDI ke Indonesia, setelah mengalami penurunan sejak krisis ekonomi 1998. Seperti terlihat pada grafik, pada tahun 2005, 2006, dan 2007 Jepang tidak lagi menjadi Negara utama yang melakukan FDI ke Indonesia, 
walau secara rata-rata 5 tahun (2005-2009) nilainya masih yang tertinggi. Berikutnya adalah Amerika Serikat dan Belanda. Keluhan utama dari para investor Jepang dalam melakukan FDI ke Indonesia adalah: : (i) masalah infrastruktur khususnya kurangnya pasokan listrik, (ii) masalah kepastian hukum, (iii) kurs mata uang yang sangat berfluktuasi, (iv) masalah keterkaitan industry hulu dan hilir, (v) masalah ketenagakerjaan, (vi) pajak ganda antara pajak pusat dan pajak daerah, dan (vii) masalah hak cipta (Suparman Zen Kemu, 2010). Hal-hal seperti ini seharusnya menjadi prioritas pemerintah untuk diperbaiki. Beberapa masalah yang masih muncul ini juga bisa memperlambat peningkatan rating Indonesia menuju ke investment grade.

Grafik 3.2.

FDI Negara-Negara Non ASEN Menurut Negara Asal

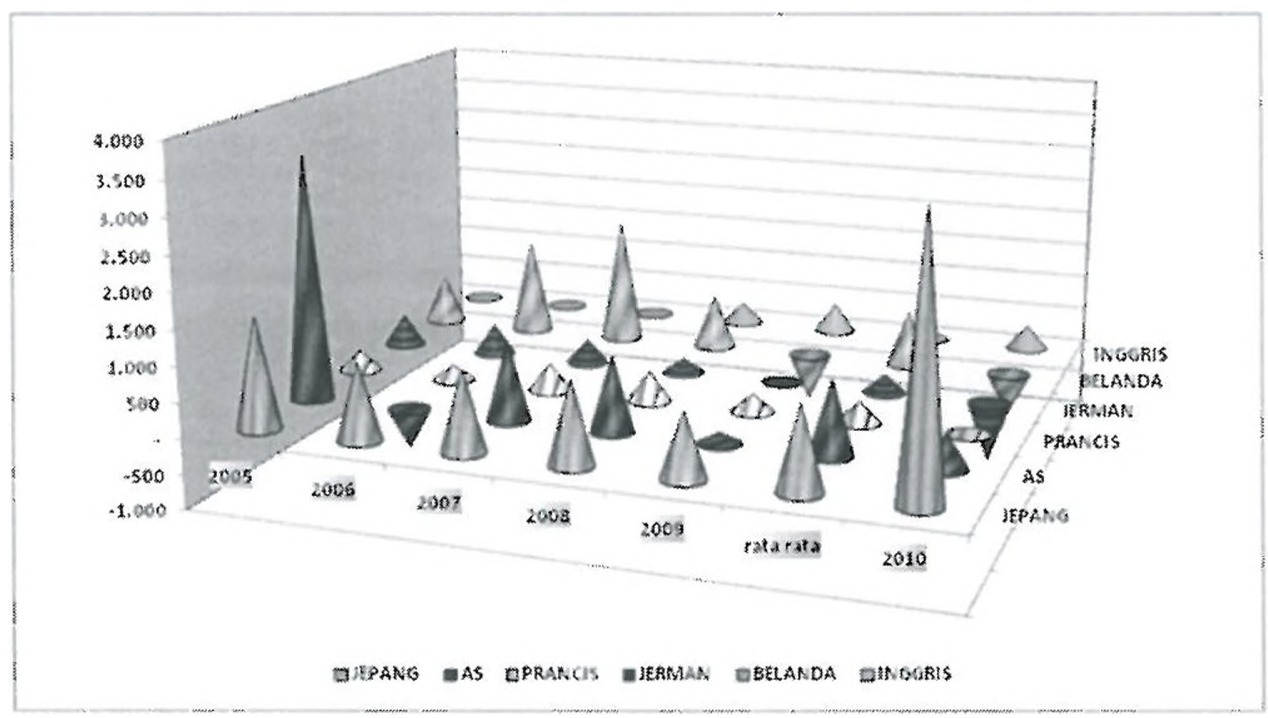

Sumber: Bank Indonesia

Pada grafik 3.3 terlihat tiga sektor ekonomi yang menarik bagi investor yang berasal dari ASEAN. Pertama sektor pengolahan yang sangat signifikan dan mencapai nilai US\$1,390 juta pada tahun 2010. Kedua adalah sektor pertambangan, dan ketiga adalah sektor pertanian.

Pada sektor pertanian termasuk perkebunan dan kehutanan Singapura memimpin dengan total investasi selama 6 tahun terakhir sebesar US\$ 362 juta, kemudian Malaysia sebesar US\$ 132 juta.. Pada sektor manufaktur, total FDI Singapura juga yang tertinggi yaitu sebesar US\$ 3,285 juta disusul oleh Malaysia dengan nilai FDI sebesar US\$ 876 juta.

Sedangkan pada sektor pertambangan pelakunya hanya Singapura dengan nilai FDI selama 6 tahun terakhir sebesar US\$963 juta. Dari data yang ada, peran 
Singapura sebagai Negara ASEAN yang FDI nya paling tinggi perlu mendapatkan perhatian, untuk dapat lebih ditingkatkan lagi diwaktu mendatang. Malaysia juga merupakan Negara ASEAN yang lumayan kontribusinya terhadap aliran masuk FDI ke Indonesia.

Grafik 3.3.

FDI Menurut Sektor Ekonomi (ASEAN)

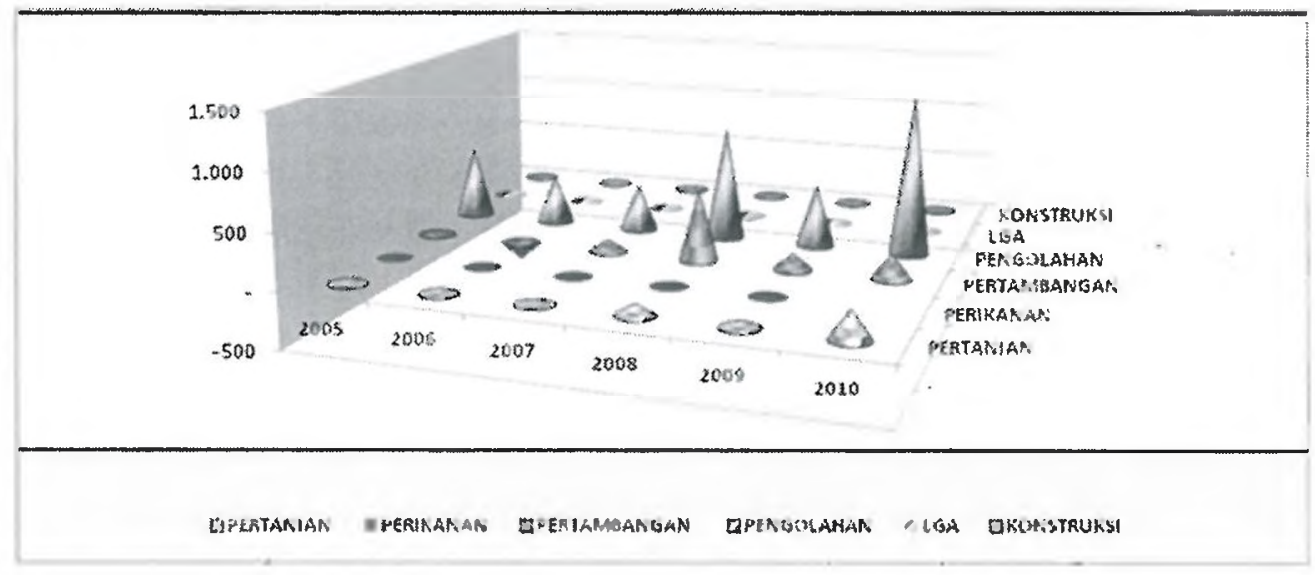

Sumber: Bank Indonesia

Pada grafik 3.4 terlihat peran Singapura yang sangat menonjol dalam melakukan FDI ke Indonesia. Walau pada tahun 2010 nilai investasi Singapura belum bisa menyamai nilai investasi pada tahun 2008, namun terjadi peningkatan yang signifikan dibandingkan dengan tahun 2009 (meningkat lebih dari 100\%). Hal Ini tidak lepas dari komitmen Singapura yang pada tahun 2010 menanamkan modalnya pada sektor infrastruktur, connectivity, pelabuhan, dan manufaktur. Sebagai pusat keuangan internasional, Singapura juga membantu mempromosikan peluang investasi Indonesia kepada pihak asing," (Hatta Rajasa/Menko Perekonomian).

Pada 2011 ini beberapa proyek patungan antara pengusaha SingapuraIndonesia juga akan direalisir dan fokus pada 10 sektor industri yaitu: kimia, minyak dan gas, permesinan, industri perhiasan, jasa penyimpanan dingin (cold storage) dan jasa pergudangan (warehousing), EO dan jasa perdagangan dunia, sistem pemompaan, manajemen industri, industri kaca pengaman, dan industri otomasi.

Dari data aliran FDI yang ada, baik dari negara-negara non ASEAN maupun dari Negara-negara ASEAN belum terlihat peranan Negara-negara anggota Islamic Development Bank (IDB) seperti Arab Saudi, Iran, Mesir, Qatar, Uni Arab Emirat, dan Mesir. Mengingat Negara-negara ini memiliki keunggulan dalam industri energi 
baik minyak dan gas bumi, serta tingginya permodalan mereka dari petro-dollar, selayaknya pemerintah memberikan perhatian kepada Negara-negara ini untuk menanamkan modalnya ke Indonesia.

Grafik 3.4

FDI Menurut Negara Asal (ASEAN)

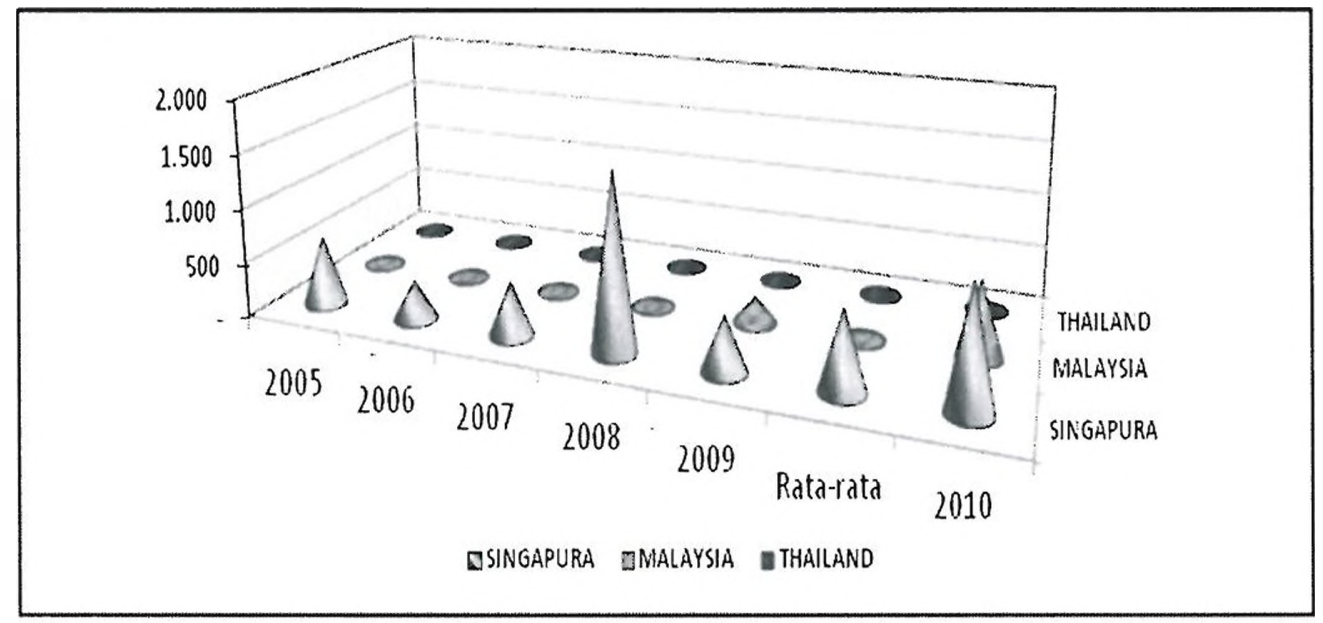

Sumber: Bank Indonesia

\subsection{Analisis Atas Sektor yang Nilai FDI nya Rendah}

Sektor Perikanan merupakan sektor yang nilai FDI nya rendah dibandingkan dengan sektor-sektor lain seperti pengolahan, pertambangan, perdagangan dan transportasi. Namun pada tahun 2010 investasi asing di sektor perikanan meningkat $71,67 \%$ menjadi US\$ 18 juta dibanding 2009 senilai US\$ 5,1 juta. Hal ini antara lain disebabkan oleh disyahkannya Peraturan Menteri Kelautan dan Perikanan (Permen-KP) No 5 Tahun 2008 tentang izin usaha perikanan tangkap. Juga disahkannya revisi UU No 31 Tahun 2004 tentang Perikanan menjadi UU No 45 Tahun 2009 tentang Perikanan. Kedua peraturan itu membuat investor asing meningkatkan investasinya pada sektor perikanan. ${ }^{6}$

Rendahnya nilai FDI pada sektor perlistrikan, gas dan air adalah karena pada sektor usaha ini masih dimonopoli oleh 3 BUMN yaitu PLN, PGN dan Pertamina, serta PAM,7 sehingga kesempatan investor asing untuk menanamkan modalnya pada sektor ini masih menemui hambatan. Untuk meningkatkan FDI pada ketiga sektor ini pemerintah selayaknya mengurangi monopoli BUMN pada sektor ini. Karena dengan adanya peran serta FDI pada ketiga sektor ini akan dapat dicapai

\footnotetext{
${ }^{6}$ Walau dari sisi investor dalam negeri kedua aturan tersebut dianggap terlampau berpihak kepada investor asing.

${ }^{7}$ PLN adalah Perusahaan Listrik Negara; PGN adalah Perusahaan Gas Negara; PAM adalah Perusahaan Air Minum.
} 
effisiensi yang optimal sehingga dapat mengurangi terjadinya distorsi ekonomi yang memberatkan konsumen dan perekonomian secara keseluruhan.

Sektor pertanian termasuk sektor yang rendah FDI nya. Hal ini disebabkan oleh keterbatasan infrastruktur jalan dan irigasi. Berdasarkan studi yang dilakukan oleh Irawan (2005), setiap kenaikan satu persen infrastruktur jalan akan meningkatkan investasi asing ke sektor pertanian sebesar 1,33\% (untuk jangka pendek), dan 7\% (untuk jangka panjang). Sedangkan kenaikan infrastruktur irigasi sebesar satu persen akan meningkatkan investasi asing ke sektor pertanian sebesar $1,98 \%$. Berkaitan dengan hasil studi ini menjadi jelas mengapa nilai FDI pada sektor pertanian selama 6 tahun terakhir sangat rendah dibandingkan dengan FDI pada sektor utama. ${ }^{8}$

\section{INSENTIF PERPAJAKAN}

Saat ini Kementerian Keuangan sedang menggodok Peraturan Menteri Keuangan (PMK) turunan dari Peraturan Pemerintah (PP) No 94/2010 yang menjadi dasar hukum bagi menteri keuangan untuk mengeluarkan fasilitas tax holiday. Walau tax holiday bukan penentu penting daya tarik investasi asing namun adanya kebijakan ini diharapkan dapat meningkatkan gairah investor asing untuk meningkatkan FDI nya di Indonesia.

Menurut Kepala Badan Koordinasi Penanaman Modal (BKPM) Gita Wirjawan, saat ini sudah ada dua investor asing yang menanti kejelasan dan kepastian dari pemerintah terkait dengan realisasi pemberian insentif keringanan fiskal berupa tax holiday tersebut. Nilai investasi dari kedua investor asing tersebut nilainya cukup signifikan, masing-masing (i) perusahaan Kuwait yang akan bekerja sama dengan PT Pertamina (Persero) untuk pengembangan kilang minyak di Balongan dengan nilai investasi USD8 miliar (sekitar Rp72 triliun). (ii) Perusahaan baja asal Korea Selatan, Posco yang siap menanamkan modalnya sebesar USD6 miliar (sekitar Rp54 triliun).

Walau tax holiday bukan merupakan prasayarat utama dalam menarik minat investor asing untuk melakukan investasi di suatu Negara, namun hal ini penting dilakukan Indonesia terutama pemberiannya diperlukan pada investasi di sektor yang kurang diminati oleh investor seperti pertanian, perikanan, dan pengolahan yang bersifat padat karya.

\footnotetext{
${ }^{8}$ Sektor Pengolahan, Pertambangan, Perdagangan, dan Keuangan.
} 
Kajian Ekonomi dan Keuangan, Volume 15, No. 2 Tahun 2011

\section{KESIMPULAN DAN REKOMENDASI}

\subsection{Kesimpulan}

Dari diskripsi dan analisis yang telah dilakukan, ada beberapa hal yang dapat disimpulkan yaitu: Untuk negara-negara non ASEAN, sektor ekonomi yang paling menjadi incaran adalah sektor manufaktur atau pengolahan yang dalam kurun waktu 6 tahun (2005-2010) porsinya 37,95\% dari total nilai investasi. Sektor kedua yang juga diminati adalah pertambangan dan penggalian sesuai dengan kondisi Indonesia yang merupakan Negara dengan sumber kekayaan alam (tambang) yang berlimpah, porsinya $21,4 \%$. Sedangkan sektor ketiga yang dimintai adalah transportasi, pergudangan, dan komunikasi, porsinya $12,51 \%$. Sektor keempat yang nilainya juga cukup tinggi adalah Lembaga Perantara Keuangan, porsinya 11,95\%. Sedangkan sektor kelima adalah Perdagangan besar dan eceran, perbaikan kendaraan bermotor, dan barang-barang rumah tangga, porsinya 9,23\%. Peranan kelima sektor ini sangat dominan karena meliputi $93,04 \%$ dari total penanaman modal asing di Indonesia.

Sedangkan negara-negara non ASEAN yang menonjol peranannya dalam melakukan investasi di Indonesia adalah Jepang (20,12\%) dari total, Amerika Serikat (12,01\%), dan Belanda 7,01\%. Beberapa Negara yang juga cukup berperan adalah Australia (4,86\%), RR China (3,72\%), Prancis (3,49\%), Korea Selatan (3\%), Luxemburg, dan Inggris masing-masing 3\% dan 2,59\%. FDI dari Jepang meningkat dengan pesat dan pada tahun 2010 mencapai US\$ 3,712 juta. Ini merupakan pertanda baik kembalinya Jepang menjadi Negara utama dalam melakukan FDI di Indonesia.

FDI dari Negara ASEAN terkonsentrasi pada sektor industri pengolahan (manufacturing) yaitu $74,42 \%$ dari total. Berikutnya adalah pada sektor pertambangan dan penggalian (16,44\%). Sedangkan sektor ketiga terbesar adalah pertanian, perburuan, dan kehutanan $(8,43 \%)$. Singapura sangat menonjol perannya dalam melakukan FDI di Indonesia. Walau pada tahun 2010 nilai investasi Singapura belum bisa menyamai nilai investasi pada tahun 2008, namun terjadi peningkatan yang signifikan pada nilai FDI Singapura dibandingkan dengan tahun 2009 (meningkat lebih dari 100\%). Hal Ini tidak lepas dari komitmen Singapura yang pada tahun 2010 menanamkan modalnya pada sektor infrastruktur, connectivity, pelabuhan, dan manufaktur. Sebagai pusat keuangan internasional, Singapura juga membantu mempromosikan peluang investasi Indonesia kepada pihak asing".

Peranan FDI dari negara-negara anggota IDB khususnya negara-negara Arab yang sangat kuat industri perminyakannya belum menonjol di Indonesia. Padahal negara-negara Arab ini sedang kebanjiran pendapatan dari minyak (petro-dollar). 
Hal ini perlu mendapat perhatian yang serius dari pemerintah dalam rangka lebih mengoptimalkan peningkatan nilai FDI ke Indonesia.

Sektor Perikanan merupakan sektor yang nilai FDI nya rendah dibandingkan dengan sektor-sektor lain seperti pengolahan, pertambangan, perdagangan dan transportasi. Namun pada tahun 2010 investasi asing di sektor perikanan meningkat 71,67\% menjadi US\$18 juta dibanding 2009 senilai US\$ 5,1 juta. Hal ini antara lain disebabkan oleh disyahkannya Peraturan Menteri Kelautan dan Perikanan (Permen-KP) No 5 Tahun 2008 tentang izin usaha perikanan tangkap. Juga disahkannya revisi UU No 31 Tahun 2004 tentang Perikanan menjadi UU No 45 Tahun 2009 tentang Perikanan. Kedua peraturan itu membuat investor asing meningkatkan investasinya pada sektor perikanan.

Rendahnya nilai FDI pada sektor perlistrikan, gas dan air adalah karena pada sektor usaha ini masih dimonopoli oleh 3 BUMN yaitu PLN, PGN dan Pertamina, serta PAM, sehingga kesempatan investor asing untuk menanamkan modalnya pada sektor ini masih menemui hambatan. Untuk meningkatkan FDI pada ketiga sektor ini pemerintah selayaknya mengurangi dominasi BUMN pada sektor ini. Karena dengan adanya peran serta FDI pada ketiga sektor ini akan dapat dicapai effisiensi yang optimal sehingga dapat mengurangi terjadinya distorsi ekonomi yang dapat memberatkan konsumen dan perekonomian secara keseluruhan.

Saat ini Kementerian Keuangan sedang menggodok Peraturan Menteri Keuangan (PMK) turunan dari Peraturan Pemerintah (PP) No 94/2010 yang menjadi dasar hukum bagi menteri keuangan untuk mengeluarkan fasilitas tax holiday. Walau tax holiday bukan merupakan prasayarat utama dalam menarik minat investor asing untuk melakukan investasi di suatu Negara, namun hal ini penting dilakukan Indonesia terutama pemberiannya diperlukan pada investasi di sektor yang kurang diminati oleh investor seperti pertanian, perikanan, dan pengolahan yang bersifat padat karya.

\subsection{Rekomendasi}

1. Indonesia sebagai Negara tujuan investasi yang menarik harus terus melakukan pembenahan pada iklim investasinya agar aliran FDI ke Indonesia di tahun 2011 ini akan terus meningkat dibanding tahun 2010 yang sudah mencatat rekor FDI yang signifikan. Apalagi kalau tahun 2012 Indonesia sudah masuk dalam investment grade, maka aliran FDI ke Indonesia diperkirakan akan lebih deras lagi.

2. Potensi keuangan yang berlimpah dari Negara-negara anggota IDB, khususnya negara Arab perlu dimanfaatkan Indonesia dengan mengundang mereka untuk melakukan investasi ke Indonesia. Karenanya, pemerintah perlu melakukan special effort atau pendekatan khusus agar para investor yang berasal dari 
Kajian Ekonomi dan Keuangan, Volume 15, No. 2 Tahun 2011

anggota IDB ini berpaling ke Indonesia sebagai Negara yang potensial bagi mereka untuk melakukan FDI.

3. Kebijakan pemberian tax holiday ke pada FDI merupakan suatu kebijakan yang tepat dan cerdas. Walau tax holiday bukan merupakan faktor utama yang menjadi daya tarik investor untuk menanamkan modal di suatu Negara, namun adanya tax holiday akan dapat mengoptimalkan peningkatan FDI ke Indonesia.

4. Beberapa sektor yang realisasi FDI-nya rendah adalah disebabkan oleh adanya kebijakan pemerintah yang terlampau berpihak kepada BUMN, seperti industri minyak, gas, perlistrikan dan air bersih. Untuk itu kedepan perlu dipikirkan adanya pemberian porsi kepada FDI untuk berusaha pada sektor usaha tersebut. Hal ini akan dapat meningkatkan efisiensi dan memberikan dampak positif kepada perekonomian secara keseluruhan.

5. Beberapa aturan teknis kepada beberapa sektor juga perlu dibuat agar dapat meningkatkan nilai FDI sektor bersangkutan. Sektor perikanan telah melakukan hal ini, dengan menerbitkan peraturan Menteri yang lebih FDI friendly, dan telah menunjukkan adanya peningkatan FDI pada sektor ini. Hal ini dapat dijadikan contoh bagi sektor-sektor lainnya yang nilai FDInya masih rendah seperti pertanian, perkebunan, konstruksi, hotel dan restoran, serta real esatate, persewaan dan jasa bisnis.

\section{Daftar Pustaka}

ADB (2009), Asian Development Outlook 2009: Rebalancing Asia's Growth, Manila: Asian Development Bank.

Asnita Frida Sebayang dan Akhmad Makhfatih: "Penanaman Modal Asing Langsung dan Efisiensi Kebijakan Fiskal Daerah di Indonesia, 1999-2002" - Program Studi Ilmu Ekonomi dan Studi Pembangunan Sekolah Pascasarjana Universitas Gajah Mada.

Budiiono, Dr : "Boediono Denies Indonesian Economy Fails" Kompas.com 10 Maret 2011.

Dwi Isti Ningsih: "Faktor-Faktor Yang Mempengaruhi Investasi Asing Langsung (Fdi) Sektor Industri Di Jawa Timur" - Fakultas Ekonomi Universitas Pembangunan Nasional "Veteran" Jawa Timur (2010).

Harian Seputar Indonesia: "PMK Tax Holiday Segera Terbit". 7 Maret 2011.

Indonesian Commercial Newsletter (ICN): "Menjaga Momentun Untuk Menarik Investor Asing" Januari 2010.

Investor Daily Indonesia: "Investasi Asing Sektor Perikanan Naik". 16 Maret 2011. Pelajaran Apa Bagi Indonesia?": Universitas Trisakti, 2009.

Suparman Zen Kemu: "Indonesia Japan Economic Relations: (Investment and Trade)" Jurnal Kajian Ekonomi Keuangan (KEK), 2010. 
Todaro, Michael: Economic Development. Longman New York \& London.

Tulus Tambunan, Anna S.N. Dasril: "Kebijakan Investasi Langsung di Vietnam dan Thailand:

UNCTAD (2008), World Investment Report 2008, New York \& Geneva: UN

Vanda Ningrum:"Penanaman Modal Asing dan Penyerapan Tenaga Kerja di Sektor Industri. LIPI Vol-III, No.2-2008.

Vivanews.com: "Tahun 2010, Singapura Siap Gelontor $\mathrm{Rp} 700$ Miliar ; Kedatangan mereka ke Indonesia, selain mencari bahan baku juga rekan untuk joint venture". 5 Maret 2010. 
